\title{
Antagonist properties of monoclonal antibodies to human CD28: role of valency and heavy-chain constant domain
}

\author{
Caroline Mary ${ }^{1,2}$, Flora Coulon ${ }^{1}$, Nicolas Poirier ${ }^{1,2}$, Nahzli Dilek ${ }^{1,2}$, Bernard Martinet ${ }^{1}$, Gilles Blancho ${ }^{1,3}$, \\ Bernard Vanhove $e^{1,2,3^{*}}$
}

From 7th European Workshop on Immune-Mediated Inflammatory Diseases

Noordwijk aan Zee, the Netherlands. 28-30 November 2012

\section{Background}

Antagonist antibodies targeting CD28 have been proposed as an alternative to the use of CD80/86 antagonists to modulate $\mathrm{T}$ cell responses in autoimmunity and transplantation. Advantages would be the blockade of CD28mediated co-stimulatory signals without impeding co-inhibitory signals depending on CD80 interactions with CTLA-4 and PD-L1 that are important for the control of immune responses and for the function of regulatory $\mathrm{T}$ cells. Anti-CD28 antibodies are candidate antagonists only if they prevent access to the CD80/86 ligands without simultaneously stimulating CD28 itself, a process that is believed to depend on receptor multimerization.

\section{Methods and results}

In this study, we used different formats of a potentially antagonist anti-human CD28 antibody and evaluated the impact on $\mathrm{T}$ cell activation of valency and of the presence of a fragment cristallisable (Fc) domain, two components that might impact receptor multimerization either directly or in the presence of accessory cells expressing Fc receptors. Among monovalent (Fab', scFv), divalent (Fab'2), monovalent-Fc $(\mathrm{Fv}-\mathrm{Fc})$ and divalent-Fc (IgG) formats, only the monovalent formats showed consistent absence of induced CD28 multimerization and of associated activation of Phospho Inositol-3 Kinase as well as clear antagonist properties in $\mathrm{T}$ cell stimulation assays. In contrast divalent antibodies showed agonist properties resulting in cell proliferation and cytokine release, in a Fc-independent manner. Conjugation of monovalent antibodies with polyethylene glycol, with a molecule of alpha-1-antitrypsin or

'Institut National de la Santé et de la Recherche Médicale Unité Mixte de Recherche-Santé 1064, Nantes, France

Full list of author information is available at the end of the article with an Fc domain significantly extended their in vivo half-life without modifying antagonist properties.

\section{Conclusion}

These data indicate that monovalency is mandatory for maintaining antagonistic activity of anti-CD28 monoclonal antibodies.

\section{Author details}

'Institut National de la Santé et de la Recherche Médicale Unité Mixte de Recherche-Santé 1064, Nantes, France. ${ }^{2}$ Effimune SAS, Nantes, France. ${ }^{3}$ Institut de Transplantation Urologie Néphrologie, Centre Hospitalier Universitaire de Nantes, Université de Nantes, Nantes, France.

Published: 28 November 2012

doi:10.1186/1479-5876-10-S3-P17

Cite this article as: Mary et al: Antagonist properties of monoclonal antibodies to human CD28: role of valency and heavy-chain constant domain. Journal of Translational Medicine 2012 10(Suppl 3):P17.

Submit your next manuscript to BioMed Central and take full advantage of:

- Convenient online submission

- Thorough peer review

- No space constraints or color figure charges

- Immediate publication on acceptance

- Inclusion in PubMed, CAS, Scopus and Google Scholar

- Research which is freely available for redistribution

\section{Ciomed Central}

○ 2012 Mary et al; licensee BioMed Central Ltd. This is an Open Access article distributed under the terms of the Creative Commons Attribution License (http://creativecommons.org/licenses/by/2.0), which permits unrestricted use, distribution, and reproduction in any medium, provided the original work is properly cited. 